Bolm. Zool., Univ. S. Paulo

$8: 107-114,1984$

\title{
SPERIMATOGENESIS IN A FRESHWATER LARGE MURREL, CHANNA STRIATUS (BLOCH)
}

SHIVAJI SRIVASTAVA

Department of Zoology, S.M.M. Town Post-Graduate College, Ballia - 277001 India. (recebido em 19.XI.1983).

RESUMO - No peixe de água doce da India, Channa striatus (Bloch), sete tipos de celulas germinativas foram reconhecidas durante o processo de espermiogênese: 1. células germina tivas em repouso, 2 espermatogōnias primárias, 3 . espermatō gōnias secundárias, 4. espermatócitos primários, 5. espermatócitos secundärios, 6. espermätides e 7 espermatozóides.0s espermatozóides nunca formam nuvens densas nos lóbulos testi culares. Eles aparecem finamente espalhados através de todö o período reprodutivo.

ABSTRACT - In the Indian freshwater large murrel, Channa striatus ( $B l o c h$ ), seven types of germ cells have been re cognized during the process of spermatogenesis viz: 1. res ting germ cells, 2 primary spermatogonia, 3 . secondary sper matogonia, 4. primary spermatocytes, 5 . secondary spermatocy tes, 6. spermatids, and 7 spermatozoa. The spermatozoa ne ver form a dense cloud in the testicular lobules. They are thinly scattered throughout the spawning period.

\section{INTRODUCTION}

There are now good accounts on the testicular structure of fishes and exellent reviews have appeared on the sub ject from time to time (Hoar, 1957, 1969; Dodd, 1960; Lofts, 1968; de Vlaming, 1974) In spite of these citations, informations on the cytological changes during the process of spermatogenesis in Indian freshwater fishes are still mea gre. In the present study, spermatogenesis is described in a freshwater large murrel, Channa striatus with special emphesis on the cytological changes occuring in the germ cells at light microscopic level. 


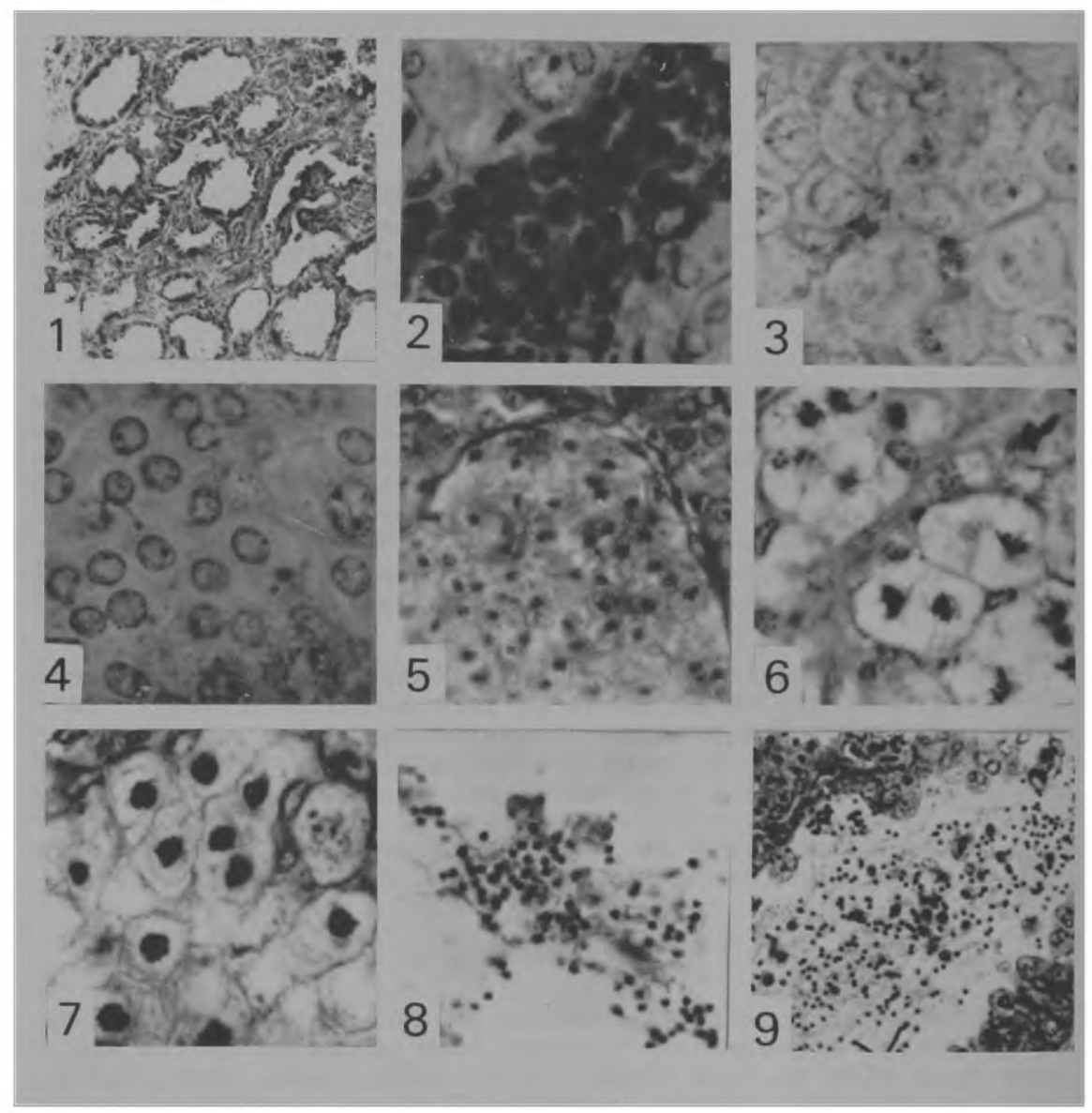

Germ cells in the testis of Channa striatus. Fig. I. Showing seminiferous lobules. H/E. X 200. Fig. 2. Showing islet of interstitial cells. H/E. X 1000. Fig. 3. Showing resting germ cells. H/E. X 1000. Fig. 4. Showing primary spermatogonia. H/E. X 1000. Fig. 5. Showing secondary spermatogonia H/E. X 630. Fig. 6. Showing primary spermatocytes. H/E. $\dot{X}$ 1000. Fig. 7. Showing secondary spermatocytes. H/E. X 1000 Fig. 8. Showing spermatids in the lobule lumen. H/E. 1000 Fig. 9. Showing spermatozoa in the lobule lumen. H/E. 1000 


\section{MATERIAL AND METHODS}

Testes of adult Channa striatus were fixed throughout the year in Bouin's solution. After routine embedding in pa-

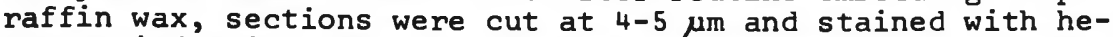
matoxylin/eosin (H/E) The testes of each month were studied for the cytological details of germ cells. The germ cells si ze were measured in each month by the aid of ocular micrometer and their average values were calculated.

\section{OBSERVATIONS}

The general histology and cyclic changes in the testes of Channa striatus have been described elsewhere (Swarup and Srivastava, 1978). The testis of Channa striatus displays ty pical organization of seminiferous lobules of connective tis sue fibres (Fig. 1) consisting of spermatogenic cysts. Each cyst is an autonomous unit with germ cells in the same stage of maturity. The early stage - germ cells lie close to the peripheral region of the seminiferous lobules where as cells at advance stages are placed centrally. Several successive divisions occur until the spermatozoa are formed. In between the seminiferous lobules islets of interstitial cells can be clearly deflected (Fig. 2). The nuclei of interstitial cells possess one or two nucleoli, a little amount of cytoplasm with ill defined cell boundary and show comparatively strong affinity to hematoxylin.

on the basis of size, nuclear and cytoplasmic events ; seven types of germ cells have been identified during the process of spermatogenesis (Tables $I$ and $I I$ ):

1. Resting germ cells: They are largest cells measuring 12.8 $\mu \mathrm{m}$ in diameter. The cell possesses large round nucleus su rounded by relatively large cytoplasmic mass. The cytoplasm is clear and cell membrane is usually distinct though faint. The nucleus contains eccentrically placed nucleolus and seve ral chromatin threads stained with hematoxylin (Fig. 3) The chromatin threads of the nucleus are seen radiating from the nucleolus. Resting germ cells occur in small numbers through out the year, but are more prominent during the resting and post-spawning periods.

2. Primary spermatogonia: They are smaller than resting germ cells and measure $6.4 \mu \mathrm{m}$ in diameter. Their cell boundaries are indistinct and cytoplasm is hyaline, surounding a dis tinct nucleus which contains sparse chromatin materials and eccentrically palced two or three nucleoli stained deeply with hematoxylin (Fig. 4)

3. Secondary spermatogonia: They are comparatively smaller than primary spermatogonia and measure $3.2 \mu \mathrm{m}$ in diameter Their cell boundaries are distinct and cytoplasmic area is thin and hyaline. (Fig. 5) Nuclei are well marked and con tain centrally placed prominent nucleolus stained deeply with hematoxylin.

4. Primary spermatocytes: The next spermatogenetic stage is 
Table I - Intensity of germ cells in the testicular lobules during annual reproductive cycle in $C$. striatus.

$\begin{array}{lllllll}\mathrm{RGC} & \mathrm{SG}_{1} & \mathrm{SG}_{2} & \mathrm{SC}_{1} & \mathrm{SC}_{2} & \mathrm{ST} & \mathrm{SP}\end{array}$

Relaxation and rehabilitation phase

Early maturation phase

Advanced maturation phase

Pre-spawning phase

Spawning phase

Post-spawning phase

+ Present, - Absent

$R G C$ - Resting germ cells, $S G_{1}$ - Primary spermatogonia, $S_{2}$ Secondary spermatogonia, $\mathrm{SC}_{1}$ - Primary spermatocytes, $\mathrm{SC}_{2}$ Secondary spermatocytes, ST - Spermatids; SP - spermatozoa 106 M.P.J. Alvarez

ZWEREVA, J.A. 1976. A new species of Aetideopsis Sars (Copepoda, Calanoida) from Aniva Bay (Okhostsk Sea) Issled. Fauny Morei, Moskwa, $20(28): 6-8$ 
the primary spermatocyte. They arise by repeated mitotic division from secondary spermatogonia. This involves polarisation of chromatin materials into one pole within the nucleus and the remaining parts of the chromosomes extend towards the centre of the nuclei forming a bouquete. This stage is called synzesis stage. Their nuclear membranes are indis tinct and deeply stained chromosome materials occupy the entire cell (Fig. 6) At this stage they measure $2.8 \mu \mathrm{m}$ in dia meter.

5. Secondary spermatocytes: They are formed by the first maturation division of primary spermatocytes. They are smaller in size. At this stage the nuclear wall becomes very dis tinct and possesses deeply stained thick clump of chromatin materials giving crystalline appearance. They measure $2.7 \mu \mathrm{m}$ in diameter (Fig. 7). Secondary spermatocytes are of short duration and soon they divide to form spermatids.

6. Spermatids: They are formed by second maturation division and measuring $1.6 \mu \mathrm{m}$ in diameter. They are characterised by the presence of uniformly condensed chromatin materials deeply stained with hematoxylin. At this stage cyst wall bursts librating the content in the lumen of the lobules.

7. Spermatozoa: Spermatids undergo the final transformation into motile spermatozoa. They are the smallest among the germ cells measuring $0.8 \mathrm{\mu m}$ in diameter. They possess a distinct rounded head stained deeply with hematoxylin and a tail stained with eosin. At this stage chromatin materials are not visible.

\section{DISCUSSION}

Studies of spermatogenesis on light microscopic level in fishes have been well described by many workers (Turner, 1919; Craig-Bennett, 1931; Matthews, 1939; Cooper, 1952; Ahsan, 1966; Hiroi and Yamamoto, 1968, 1970; Hyder, 1969; Swarup and Srivastava, 1978, 1979) In Channa striatus during the process of spermatogenesis a progressive cytological chan ges occur followed by a gradual decrease in the size of sper matogonial cells. The gradual reduction in the size is carried upto spermatid formation which metamorphose into spermatozoa by reduction in its nuclear size and production of a vibratile tail. Seven types of germ cells have been identi fied in the process of maturation. The resting germ cell is characterised by its large size and distinct cytoplasmic and nuclear materials. They are more in number at the periphery of the testicular lobules. The resting germ cells divide to form primary and secondary spermatogonia. These stages of germ cells are characterised by a gradual decrease in their size and showing prochromosomal and leptotene stages of sper matogonia. The next stage is primary spermatocytes which pas ses through various stages of division and finally reduces in size. They are characterised by the formation of synzesis knot. The primary spermatocytes undergo first maturation division to give rise to the reduced number of chromosomes of the secondary spermatocytes. Secondary spermatocytes is a 


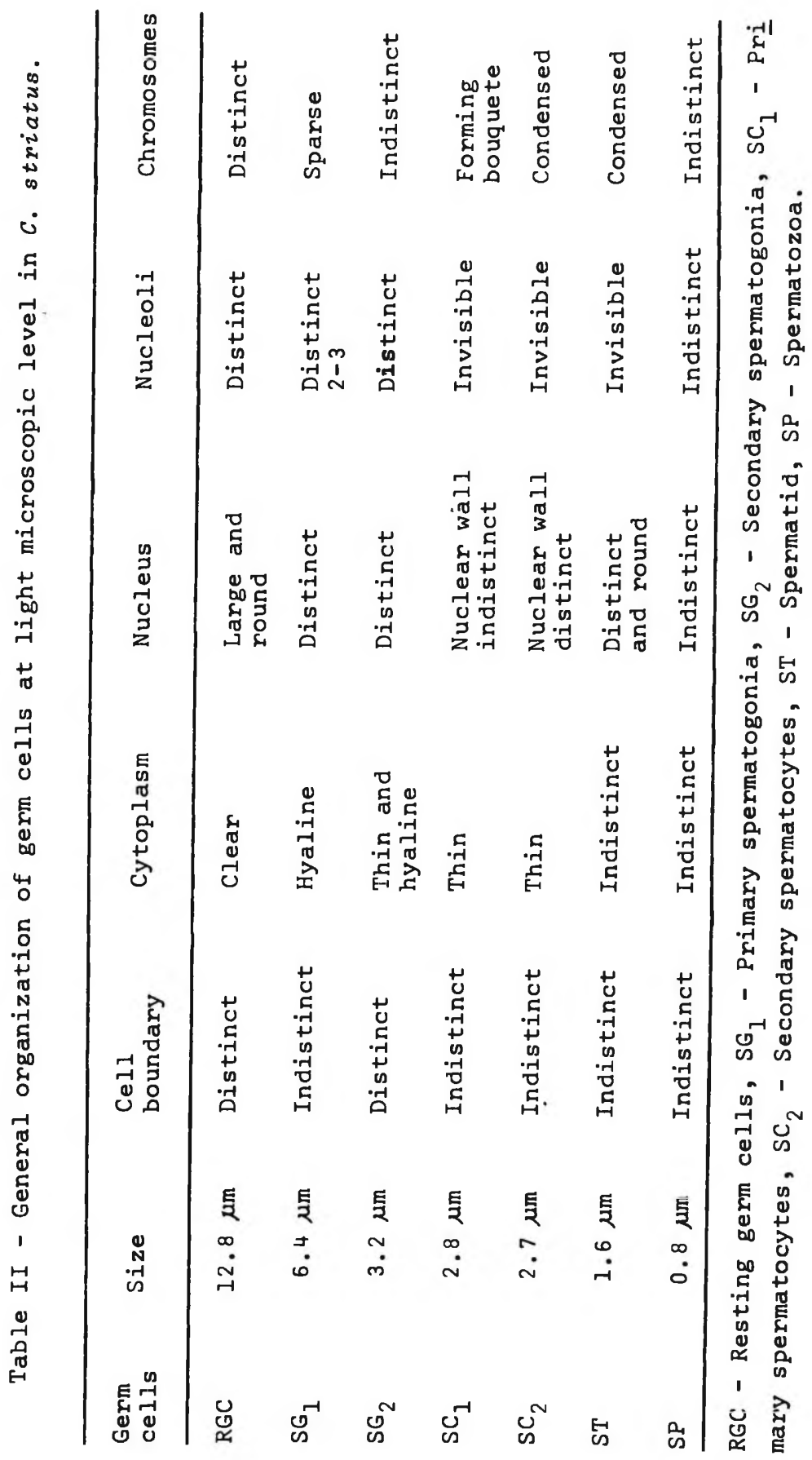


comparatively transient phase in the spermatogenetic cycle. Several other workers also agreed with this view (Foley, 1926 ; Vaupel, 1929, Bullough, 1939; Weisel, 1943; Ahsan 1966). The spermatids are formed by the second maturation di vision of secondary spermatocytes which finally transform in to motile spermatozoa. At the spermatid stage the cyst wal break open to release them into lobule lumen. Similar observations have been made by other workers (Graig-Bennett,1931; Bullough, 1939; Ahsan, 1966; Hyder, 1969; Swarup and Srivastava, 1978, 1979)

According to Hoar (1969) ' Spermatozoa are formed from the sperm mother cells or spermatogonia through a series of cytological stages collectively reffered to as "Spermatogene sis" This process involves a proliferation of spermatogonia through repeated mitotic divisions and growth to form primary spermatocytes; these then undergo reduction division to form secondary spermatocytes; the division of secondary sper matocytes produces the spermatids which then metamorphose in to the motile and potentially functional gametes - spermatozoa, spermia or sperm' In Channa striatus spermatogenesis involves two types of multiplication processes: 1) Mitotic phase - this is very slow and the nuclear division is mito tic upto primary spermatocyte, and 2) Meiotic phase - this is rapid and of short duration in which secondary spermatocy tes and spermatids are formed which finally transform into spermatozoa. Similar situations have been reported by other workers (Boullough, 1939; Harrington, 1957; Ahsan, 1966).

Like other teleosts, the lobules of the testis of Chan na striatus are never found packed with spermatozoa. They are thinly scattered in the testicular lobules throughout the spawning period. It seems that they pass regularly into the sperm duct immediately after their formation and are finally discharged.

After spermiation, new spermatogenetic stages start forming. At this stage the lobules are empty except for thin remenents of spermatozoa. Spermatogenesis is reinitia ted shortly after spermiation and new cysts of early germ cells begin to appear.

\section{REFERENCES}

AHSAN, S.N. 1966. Cyclical changes in the testicular activity of the lake chub, Couesius plumbeus (Agassiz) Can.J. 2002. 44(2):149-159.

BULLOUGH, W.S. 1939. A study of the reproductive cycle of the minnow in relation to the environment. Proc.Zool.soc. London 109:79-102.

COOPER, L.J 1952. A histological study of the reproductive organ of crappies (Phomoxis nigromnaculeatus and Phomoxis annularis) Trans.Am.Micro.Soc. 71:393-404.

CRAIG-BENNETT, A. 1931. The reproductive cycle of three spined sticle-back, Gastrosteus aculeatus Linn. Phil. Trans. Roy.Soc.London 219:197-279.

de VLAMING, V.L. 1974. Environmental and Endocrine Control of Teleost Reproduction. In Control of Sex in Fishes SCHRECK, C.B. ed. PP. 13-83. Sea Grant and Verginia Poly- 
technique Institute and State University Press, Blacks burg.

DODD, J.M. 1960. Gonadal and gonadotrophic hormones in lower vertebrate In Marshall's physiology of Reproduction. Vol. I PARKES, A.S. ed. Pp. 417-582. Longmans Green, New York. FOLEY, J.G. 1926. The spermatogenesis of Umbra $l_{i m i}$ with spe cial reference to the behaviour of the spermatogonial chro mosomes in the first maturation division. Biol.Bull. 50 : 117-140.

HARRINGTON, R.W. 1957 Sexual photoperiodicity of the cyprinid fish, Notropis bifrenatus (Cope) in relation to the phases of its annual reproductive cycle. J.Exp.Zool. 135: 529-556.

HIROI, O. \& YAMAMOTO, K. 1968. Studies on the maturation of Salmonid fishes - I. Changes in the testis of Chum sal mon, Oncorhynchus keta during anadromous migration. Bull. Fac.Fish. Hokkaido Univ. 19(3):173-184.

HIROI, 0. \& YAMAMOTO, K. 1970. Studies on the maturation of salmonid fish, II. Changes in the testis of the masu salmon, Onchorhynchus masou during anadromous migration.Bulz. Fac.Fish. Hokkaido Univ. 20(4):252-264.

HOAR, W.S. 1957 The gonads and reproduction. In The Physiology of Fishes. BROWN, M.E. ed. Vol. I. Pp. 287-321. Academic Press New York. London.

HOAR, W.S. 1969. Reproduction. In Fish Physiology. HOAR, W. S. \& RANDALL, D.J. eds. Vol. III. Pp. 1-72. Academic Press, New York and London.

HYDER, M. 1969. Histological studies on the testis of Tila pia leucosticta and other species of the genus Tilapia (Pisces: Teleostei). Trans.Amer.Micros.Soc. 88(2):211-231.

LOFTS, B. 1968 . Patterns of testicular activity. In Perspectives in Endocrinology. BARRINGTON, E.J.W. \& JORGENSEN, C. B. eds. pp. 239-304. Academic Press. New York. London.

MATTHEWS, S.A. 1939. The relationship between the pituitary gland and gonads in Fundulus. Biol. Bull. 76:24l-250.

SWARUP, K. \& SRIVASTAVA, S.J 1978. Cyclic changes in the testicular activity of the freshwater large murrel, Channa striatus (Bloch) Arch. de. Biol., Bruxelles, 89(3): 329-342.

SWARUP, K. \& SRIVASTAVA, S.J 1979. Cyclic changes in the testicular activity of the freshwater large murrel, channa marulius (Ham.). Nat.Acad.Sci.Letters $2(2): 83-84$.

TURNER, C.L. 1919. The seasonal cycle in the spermary of the perch. J.Morph. 32:681-711.

VAUPEL, J. 1929. The spermatogenesis of Lebistes reticulatus. J.Morph. \& Physiol. 47(2):555-585.

WEISEL, G.E. 1943. A histological study of the testes of the sokeyed salmon, Oncorhynchus nerka. J.Morph. 73:207-230. 